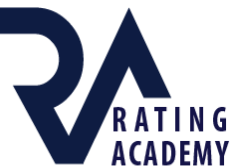

\title{
Journal of Arts
}

Cilt / Volume 2, Sayı / Issue 3, 2019, pp. 129-140

E - ISSN: 2636-7718

URL: https://ratingacademy.com.tr/ojs/index.php/arts/index

DOI: https://doi.org/10.31566/arts.2.009

Araştırma Makalesi / Research Article

\section{BİR MÜZİK FILLOZOFU OLARAK SCHOPENHAUER}

\section{SCHOPENHAUER AS A MUSIC PHILOSOPHER}

\author{
Suat Soner ERENÖZLÜ * \\ * Dr., Antalya Üniversitesi, TÜRKIYE, E-mail: suatsonererenozlu@gmail.com \\ ORCID ID: https://orcid.org/0000-0002-7789-7675
}

Geliş Tarihi: 23 Haziran 2019; Kabul Tarihi: 27 Temmuz 2019

Received: 23 June 2019; Accepted: 27 July 2019

\section{$\ddot{O Z Z E T}$}

Sanat felsefesi veya daha genel olarak estetik doktrinler, Antik Yunandan beri felsefenin temel konularının belirlendiği tartışmalardan oluşmaktadır. Güzelin ne olduğunun araştırılmasına yönelik olan çalışmalar Antikçağda başlamış, ancak Kant'ın Yargı Yetisinin Eleştirisi'yle birlikte sistemli bir şekilde ele alınmıştır. Schopenhauer'dan önce estetik konusuyla ilgilenen filozoflar, ayrı bir müzik felsefesi ortaya koymak gibi bir ihtiyaç içinde olmadan, müzik sanatını kendi sistemlerinin içerisinde tutarlı bir şekilde ele almışlardır. Bu filozofların düşünceleri, müzik felsefesi literatürünün ilk çalışmaları olarak, alanında bir temel oluşturduğu kabul edilebilir.

Bu çalı̧̧mada; Schopenhauer'un müzikle ilgili düşüncelerinde kendisinden önceki filozoflardan nasıl etkilendiği, onlara yönelttiği eleștiriler ve konuyla ilgili iddialarının müzik felsefesindeki yeri araştırllacaktır. Bununla birlikte Schopenhauer'un müzikle ilgili düşüncelerinin, bir müzik felsefesi adını alması için olanaklı olup olmadığının da araştırılması üzerinde durulacaktır.

Anahtar Kelimeler: Schopenhauer, Müzik felsefesi, Sanat Felsefesi, Estetik

\section{ABSTRACT}

The philosophy of art, or more generally, aesthetic doctrines, has consisted of debates on the basic subjects of philosophy since Ancient Greece. The studies on the investigation of what is beautiful started in Antiquity; however, they were handled systematically together with Kant's Critique of Judgement. Philosophers interested in aesthetics prior to Schopenhauer dealt with the art of music consistently within their own systems, without the need for a separate philosophy of music. The views of these philosophers can be considered as a foundation in this field as the first studies of the literature of the music philosophy.

This study will explore how Schopenhauer's thoughts about music were influenced by the philosophers before his time, his criticisms towards them and the role of his relevant claims in the philosophy of music. In addition, the study will also focus on whether Schopenhauer's views on music are likely to be called a music philosophy.

Key Words: Schopenhauer, Philosophy of Music, Philosophy of Art, Aesthetic 


\section{GİRIȘ}

Felsefe tarihine bir göz atılacak olunursa, müzik felsefesi çalışmaları 19. yüzyılın sonlarında kendini göstermiştir. Hanslick'in 1854 yılında yayımladığı Müzikal Güzel Üzerine (On The Musically Beautiful) çalışması bu alanın ilk örneklerinden birisidir. Bu tarihe kadar müzik felsefesi üzerine yapılan çalışmalar, fillozofların kendi dizgelerinin içerisinde bu konuya olan alakalarını yansıtmaktadır. Başka bir ifadeyle felsefe tarihi içerisinde filozoflar, müzik felsefesini kendi başına ele alacak kadar önemsememişlerdir. Schopenhauer'un müzik konusunu ele alış şekli de, genel olarak felsefesini yansıttığ İsteme ve Tasarım Olarak Dünya (1819) adlı eserinin üçüncü bölümüyle sınırlı olduğu düşünülürse, kendisinden önceki filozofların izinden gittiği söylenebilir. Ancak Schopenhauer, sanat veya müzik sanatını kendi başına ele almamış olsa bile, özellikle müzik hakkındaki görüşleri bir devrim niteliğindedir ki, "Schopenhauer'un yaptığı devrim, müzik duygusunun teorisi olarak 19. yüzyıldaki iki devrimden birisidir"” (Kivy, 2010: 22). Schopenhauer'un bu devrimi müzik felsefesi çalışmaları olarak başta Hanslick'i etkilediği düşünülse de, bu çalışmaların bir müzik felsefesi olarak önem kazanıp kazanmayacağı tartışmaya açık bir konudur. $\mathrm{Bu}$ bağlamda Schopenhauer'un genel felsefesinin içerisinde müzikle ilgili düşüncelerinin yerinin ne olduğunun araştırılması önem taşımaktadır. Böyle bir araştırmanın yöntemi, öncelikle Schopenhauer'un genel felsefesinin temel prensipleri ve ona yakın düşüncelerle kurduğu bağların izinin sürülmesiyle mümkün gözükmektedir. Ardından Schopenhauer'un sanata dair görüssleri, yine benzer tartışmalarla olan bağlarıyla ele alındıktan sonra ancak Schopenhauer'a ait bir müzik felsefesinin olanaklılı̆̆ kendisini belli edecektir.

Müzik felsefesi tarihine bakıldığında, hangi boyutta katkı sağladığına bakılmaksızın bu alanda eser veren bütün filozofların tek bir çatı altında toplanması ve birbirleri arasındaki bağın kurulması felsefe araştırmalarının temel yöntemini oluşturmaktadır. $\mathrm{Bu}$ bağlamda Schopenhauer'un müzik felsefesi üzerine yapılan bu çalışma, müzik felsefesini tarihselliği ve tinselliği içerisinde bir bütün olarak ele almıştır. Aynı zamanda, Schopenhauer'un felsefesinin kendisinden önceki filozoflardan etkilendiği ve kendisinden sonrakileri etkilediği noktalarla birlikte, felsefesinin yerini, müzik felsefesi tarihi içerisinde saptamaya çalışmaktadır. Bundan dolayı da bu çalışmanın ana problemi Schopenhauer'un müzik düşüncelerinin, bir müzik felsefesi olarak olanaklı olup olmadığıdır.

\section{SCHOPENHAUER'UN FELSEFESI}

Lukacs, Schopenhauer'dan “Bilgi kuramsal öznelciliğin ve felsefi usdışıcılığın ünlü bir temsilcisi" (Lukacs, 2001: 78) olarak bahsederken, onun felsefesinin büyük ölçüde Kant'1n transandantal öznesi ve Platon'un idealar düşüncesiyle yapılandığına işaret etmektedir. Dahası, Maurice Dupuy, Schopenhauer'un felsefesini Kant'ın çizgisine daha yakın görerek, onu Kant'ın varisi olarak göstermekte bir sakınca görmemiştir (Sans, 2006: 24). Buna karşın ironik olarak, Schopenhauer'un en çok etkisinde kaldığı filozofun Hegel olduğu da düşünülebilir. Şöyle ki, Schopenhauer dönemin en popüler ve başarılı filozofu olarak görülen Hegel'in gölgesinde kalmış, bu durumun öfkesiyle meydan okumak için derslerini aynı saate koymuş, Hegel'in savunduğu tarihselliğe ve tin (geist) felsefesine şiddetle karşı çıkmış, bir nevi ona savaş açmış ve bu karşı duruşu ile felsefesine belirli bir yön vermiştir. Bundan dolayı Hegel'in felsefesi ne kadar tinsellik ve olgusallık gibi yaşam dünyasında nesnelleşen kavramlardan güç alıyorsa, Schopenhauer da bir o kadar idealar ve istemeyle nesnel dünyadan uzaklaşmak arzusundadır. Schopenhauer'un felsefesini etkileyen bir başka unsur da; Hindistan'ın çok eskiye dayanan bilgeliğiyle erken yaşlarında okuduğu Upanişad ${ }^{2}$ metinleriyle başlayan, doğu felsefesine olan ilgisidir (Saunders, 2006: 54). Bu eski metinlerin mistik özelliği ve pratik yanı Schopenhauer'u Modern Batı felsefesinin karşısında, Descartes'ın cogito önermesi temelinde aklın egemenliği ve aklın kurduğu dünya anlayışının tam tersi yönde etkilemiştir. Başka bir deyişle Schopenhauer, felsefesini modernlerin yaptığı gibi aklın hükümdarlığının ve ahlak 
merkezciliğinin aksine, istek ve idea üzerine kurmuştur. Onun bu teşebbüsü Descartes'dan beri süregelen ve aklı merkeze koyan bir felsefi geleneğinin yön değiştirerek merkezinin akıldan isteğe doğru kayması anlamına gelmektedir. Artık istek merkezli bir felsefe, "rasyonelliği insanın özü olarak tanımlamaz. Schopenhauer'a göre, hayvanlarda olduğu gibi, bizim de özümüz istençtir. Sadece insanın akla sahip olduğu ve onun için sadece insanın ahlaki olarak dikkate değer olduğu fikrini de reddeder" (Cartwright, 2014: 263).

Schopenhauer'un sanat ve estetikle ilgili düşünceleri, felsefesinin genel hatlarıyla birlikte, felsefesinin temelini attığı Isteme ve Tasarım Olarak Dünya adlı eserinde ortaya çıkmaktadır. Dört bölümden oluşan bu eserin ilk bölümünde, bireyin bir tasarımı olarak var olan dünya, özne-nesne ilişkisiyle açıklanır. Schopenhauer’a göre, "dünya, ancak başka bir şeyle ilişkisi içinde, tasarımı kavrayan biriyle ilişkisinde vardır, bu da kendisidir" (Schopenhauer, 2009: 7). Başka bir ifadeyle; algilayan, kavrayan, bilen bir özne olmazsa, tasarım olarak nesne de var olmaz. Kant'ın transandantal öznesinin açık bir şekilde etkisinin görüldüğü bu bölüm, dünyanın bir tasarım olarak özneye bağlandığını ortaya koymaktadır. İlk bölümde algılanan dünyanın yapılandırılmasının ardından, ikinci bölümde öznenin bu yapılandırmada üstendiği rolü ele alır ve bu bağlamda özneyi; yeter sebep ilkesinden bağımsız, nedensiz ve öz olan olarak istenç problemi üzerinden ele alır. Her tasarım, fenomenlerden güç alırken; uzam, zaman ve duyumsamanın koşullarıyla kendisini belli eder. Dolayısıyla tasarım ne kadar koşullara bağlı ise, istençte o kadar özgürdür, hiçbir nedenle açıklanamaz, insanda karakter, nesnede nitelik olarak ortaya çıkar ve bilinçle bağlantısız, kendinde şey olarak vardır. "kendinde şey, istemenin -nesne olmamış, daha tasarıma dönüşmemiş istemenin -ta kendisidir" (Schopenhauer, 2009: 121). Buradan çıkarılacak sonuç, kendinde şeyin salt isteme olarak değil, nesneye yönelmiş olarak (potansiyel olarak) tasarımın nedenidir. Schopenhauer, bu noktada Kant'1n kendinde şey (ding an sich) kavramına, nesnel varlıkları yok saydığı ve onlardan (nesnelerden) tamamen bağımsız olduğu gerekçesiyle bir eleştiri getirmektedir. Bu bağlamda Schopenhauer için Kant'ta tutarsızlık olarak gördüğü bu durumdan kurtulmanın bir tek yolu vardır, o da Platon'un idealarının nesnelleşmesidir. Ancak bu yolla istenç, özne ile nesne arasındaki ilişkiyi tesis edebilmektedir (Schopenhauer, 2009: 121). Schopenhauer'un öne sürdüğü bu yeni anlamıyla kendinde şey kavramının, Kant ile Platon arasında bir uzlaşma sağlandığı ileri sürülebilir. Böylece Schopenhauer İsteme ve Tasarım Olarak Dünya adlı eserinin ilk iki bölümünde, özne-nesne arasındaki ilişkinin boyutlarını belirledikten sonra, üçüncü bölüme geçer. Bu bölümde güzel, yüce, deha vb. kavramlarla Kant'ın sanat felsefesinde açtığı yolda ilerlerken, aynı zamanda Platon'un idealar kuramının etkileri de açık bir şekilde gözlenmektedir. Schopenhauer, özellikle özne-nesne ilişkisine dayanan klasik anlayışın dışına çıkarak, estetik anlayışını başka bir boyutta yapılandırma gayretinde olmuştur. Schopenhauer'a göre "Nesne, nesne dışındaki bütün ilişkilerin dışına çıkma noktasına ulaşmışsa, özne de istemeyle tüm ilişkilerinin dışına çıkmışsa, bilinen artık bireysel bir şey değil bir ideadır, bengi bir kalıptır, istemenin bu basamakta doğrudan nesne olmasıdır. Bu algıda kendinden geçen kişi, bu yüzden artık birey de değildir. O, saf, isteksiz, acısız, zamansız bilgi öznesidir" (Schopenhauer, 2009: 125).

Schopenhauer'un diğer bölümlere nazaran daha çok üzerinde durduğu ve insan eylemlerini konu aldığ 1 dördüncü ve son bölümde, istemenin özü olarak hayatta kalma güdüsü üzerinde durur. Dolayısıyla, üremenin, canlı olmanın, hayatta kalma hazzının insan yaşamının bir parçası olduğu kadar, ölümün de doğal olarak kabul edilmesinin yaşama dahil olduğunu ve bu yüzden de insanın öleceğini bilerek yaşamasının rahatsız edici olmadığını iddia eder (Schopenhauer, 2009: 219). Onun pesimist bir filozof olarak algilanabileceği bu bölümde, ölümün sadece görüngü olarak bir son olduğu, istemenin sonsuz, daha doğrusu zamansız olduğunu vurgulaması dikkat çekici gözükmektedir. Schopenhauer, Isteme ve Tasarım Olarak Dünya adlı eserinin son bölümünde ortaya koyduğu temel kavramlar olan isteme, sonsuzluk, 
haz, acı vb. gibi kavramların, sanat ve müzikle ilgili düşünceleriyle desteklememesi, felsefesinin bütünü düşünüldügünnde estetiğe olan ilgisinde bir kopma olarak düşünülebilir. Bununla beraber çalışmasının ilk üç bölümünün özne-nesne ilişkisi üzerinden yapılandırması ve isteğin nesnelleşmesi konularıyla, Schopenhauer'un estetik ve sanat felsefesinin temel ilkelerini belirlediği de gözden kaçmamalıdır.

$\mathrm{Bu}$ bağlamda akıllarda, Isteme ve Tasarım Olarak Dünya adlı eserinde felsefesinin temel ilkelerini belirleyen Schopenhauer, sanat felsefesi veya estetikle ilgili düşüncelerinde belirli bir dizge -oluşturdu mu? -Oluşturamadı mı? sorusu cevap aramaktadır.

\section{SCHOPENHAUER'UN FELSEFESINDE SANAT VE ESTETIKK}

Schopenhauer sanat ile felsefeyi birbirine çok yakın olarak görmüş, ikisini de dünyanın özünün yorumlayıcısı olarak kabul etmiştir, "çünkü ikisi de ister istemez tefekkürcü bakışa yönelmiştir, şeylerin özüyle doğrudan temas halindedirler” (Sans, 2006: 54). Schopenhauer'a göre sanat; tasarım veya yaratıcılık olarak ideaların bilgisiyle oluşur, teknik olarak da amaçlanan bu birikimlerin iletilmesidir. Başka bir ifadeyle İdealar sanatın kaynağını oluştururlar ve sanat varlığının ortaya çıkabilmesi için onların nesneleşmesi bir zorunluluk olarak gözükmektedir. Bu nesnelliğin oluş biçimine göre de sanatın türü kendini belli eder. Yani idealar taş veya sert bir cisim (bronz, gümüş) ile nesnelleşiyorsa, heykel; boya malzemeleriyle nesnelleşiyorsa, resim; notalarla (sesle) nesnelleşiyorsa müzik sanatı adını alır. İdeaların görüngülere taşınmasında, yani nesnelleşmesinde bir edimsel bir güce ihtiyaç vardır ki, bu güç sanatın yaratıcısı olan dehanın kendisidir. Sanatın yaratıcısı olarak deha, bilginin kaynağı olan kavramlardan bağımsız, sezgileriyle ve kavradığı idealar ile sanatını oluşturur. Schopenhauer'un ardından özellikle Edmund Husserl ve Marleau-Ponty'nin başını çektiği fenomenolojik estetiğin kurucu öznesi, bu ilkelerle, yani bilgiden bağımsız, sezgilerinin ve idealarının bütünü olan salt algılarıyla sanat nesnesine yöneleceklerdir. Schopenhauer, Kavramları kendilerine kaynak edinen sanatçıları taklitçi olarak görür ve onların eserlerini sanat eseri olmaktan uzak ve kalıcılıktan yoksun olarak değerlendirir. Deha, sanatın yaratıcısı olarak delilik sınırlarında dolaşan, yeter sebep ilkesinden bağımsı, nesnelerin bilgisinden çok onların idealarını bilme yeteneğine sahip, bilmenin saf öznesi olarak tanımlanmaktadır. Ama dehanın asli görevi, kavradığı bu ideaları, sanat eseri aracılığı ile aktarabilmesidir (Schopenhauer, 2009: 132-140).

Schopenhauer, Isteme ve Tasarım Olarak Dünya adlı eserinde sanatları, ne Kant'in Yargl Yetisinin Eleştirisi'nde belirttiği gibi "biçimlerine veya duyumlarına göre" (Kant, 1952: 184), ne de Hegel'in Estetik Dersleri'nde belirttiği gibi tinsellik ve tarihselliğe göre (Hegel, 2004: 84-85) bölümlere ayırır. Bunların yerine Schopenhauer, sanatı hem varoluş, hem de teknik özellikleriyle irdeleyerek hiyerarşik bir ayrıma götürmeyi kendine daha yakın görür. $\mathrm{Bu}$ bağlamda, sanatları en alt ve en üst olmak üzere iki basamağa ayıran Schopenhauer, sanatın nesnesi olan maddeyle, onun ideasına olan mesafesini kendisine ölçüt olarak belirler. Başka bir ifadeyle sanatın nesnesi olarak somutlaşan ve ideadan uzaklaşan sanat ile soyut bir ifade ile ideaya daha yakın ve sanat nesnesiyle varolma temeline dayanmayan bir anlayışla sanatı iki bölüme ayırır. Alt basamağı görüngülerle olan bağlantısı nedeniyle somut sanatlar oluştururken, üst basamağı idealara daha yakın olarak varlık gösteren soyut sanatlar oluşturmaktadır. Böylece Schopenhauer kendisinden önce fenomenler üzerinden yapılandırılan estetik anlayışların hepsini sanat nesnesine yakınlığından dolayı kendi estetik anlayışında en alt kademeye yerleştirir. Schopenhauer'a göre görüngülerde beliren en alt basamak olarak mimari ve plastik sanatlar yer almaktadır. Bir yapıyı ayakta tutan şeyin doğaya uygunluk olduğunu belirtmesi, mimarinin malzemesinin doğanın zorunluluğu olan fizik kuralları olduğu anlamına gelmektedir. Buradan da anlaşılacağı gibi Schopenhauer, sanatın en alt basamağı olarak maddeyi ve onun doğa yasalarıyla olan ilişkisini belirlemiştir. Schopenhauer heykel ve resim sanatını, mimarlıktan farklı olarak en alt basamağın biraz üstünde olarak tahayyül eder. Mimari 
eserlerin doğanın bir kopyasını oluşturmak gibi bir gayesi yokken, heykel ve resim sanatı; hayvanların, bitkilerin, insanların, doğa güzelliklerinin kopyalarını üretmek üzerine çalışır (Schopenhauer, 2009: 169). Başka bir ifadeyle mimari eserler fonksiyonel olmaları zorunluluğundan dolayı doğaya uyumlu ve doğanın bir parçası olarak var olurken, resim ve heykel sanatı ise salt seyir için üretilen (doğanın) tasvir eserleridir.

Schopenhauer, sanatın basamaklarının en üst kısımlarını idealara olan yakınlıkları ile belirler. "Her sanatın ortak amacı, her sanat nesnesinde kendini açığa vuran ideayı, her basamakta kendini nesneleştiren istemenin ideasını açmak, açık kılmaktır" (Schopenhauer, 2009: 190). Bu bağlamda yazın sanatı da, yaptığı betimlemelerden ötürü, doğanın taklidi olarak idealardan uzak bir basamakta yer almaktadır. Schopenhauer'a göre ancak müzik sanatı görüngülerden bağımsız olarak ve saf idea olarak, sanat için oluşturabilecek basamağın en üstünde yer almaya hak kazanır.

"O (müzik sanatı) bütün başka sanatlardan kopuk, tek başına durur. Müzikte dünyadaki yaratıkların ideasının taklidini, yeniden üretimini saptayamayız. O, büyük, parlak bir sanattır. Müziğin insanın en derin doğası üzerindeki etkisi çok çok güçlüdür. Yetkin, evrensel bir dil olarak, insanın en derin bilincinde derinlemesine, tam olarak anlaşıllur" (Schopenhauer, 2009: 194)

Dolayısıyla Schopenhauer'un müzik sanatına bakışı güzel sanatların bir alanıymış gibi değil de, güzel sanatlarla (daha doğrusu görsel sanatlarla) müzik sanatı iki farklı bir alan olarak varlıklarını sürdürdüklerin kabulü ile olanaklı gözükmektedir. Bu ayrılık, Schopenhauer'un idealarda ortaya çıkan ve özgür istemenin saf bir ürünü olarak gördüğü müzik sanatını, nesnelleşmeye ihtiyaç duymadan bizatihi idealarda bulunan bir sanat hadisesi olarak görmesinden kaynaklanır.

\section{SCHOPENHAUER'UN MÜZİK FELSEFESI}

Sanat felsefesinin kapsamı içerisinde filozoflar, müzik sanatı ile ilgili düşüncelerini aktarırken oldukça dikkatli davranma zorunluluğu hissetmişlerdir. Bunun en önemli nedeni olarak, Schopenhauer'un iddia ettiği gibi müziğin soyut bir sanat olduğu gösterilebilir. Müzik sanatı, performansa dayanan soyut bir sanat olarak varlık gösterdiği içindir ki, onun hakkında düşünürlerin sarf ettiği yaklaşımlar somuta indirgeme eğilimli olup, genellikle müziği oluşturan teknik konularla alakadar olmaktan öteye geçememiştir. Bu konular başlıca, seslerin dizileri (scales), uyumları (harmony) ve ritimleri (rhythm) olarak varlık göstermektedir. Çünkü bunlar müziği oluşturan temel yapı taşlarıdır ve somuta indirgenebilirler, dolayısıyla da haklarında rahatlıkla bir açıklama veya eleştiri getirebilme imkanı vardır. Felsefe tarihinde, temeli Antik Yunanda atılan müzik yaklaşımları, somuta indirgenen müziğin düşüncesi olarak uyum ve oranın konusunu kapsayan matematik; ahlak, eğitim ve ruhu arındırmanın (katharsis) konusunu kapsayan etik ve iyi bir vatandaş olmayla birlikte kısmen ahlakla ilgili olarak da politika ile sınırlı bir alakada ele alınmıştır. Ancak 18. yüzyılda Kant ile birlikte sanatın insan tarafından nasıl algılandığı ve estetik problemlerin özne ve onun yetileri ile şekil aldığı bir ortam meydana gelmiştir. Schopenhauer'a felsefe yapabilecek uygun bir zemin olarak kabul edebileceğimiz bu birikimler, filozofun sanatlar ve müzik üzerine daha soyut düşünebileceği ortamı hazırlamıştır.

Schopenhauer müzik sanatını diğer bütün sanat dallarından ayırmaktadır. Böyle bir ayrıma ihtiyaç duyması, müzik sanatının en yüce sanat olduğunu düşünmesinden kaynaklanır. $\mathrm{Bu}$ yüce sanat gücünü doğanın bir taklidinin veya tekrar üretiminin mümkün olmadığ düşüncesinden almaktadır. Müzik sanatı diğer sanatların aksine mimesis ${ }^{3}$ ile ifade edilmesi mümkün olmayan ve idealarla bağlantılı olarak istemenin kendisidir (Schopenhauer, 2009: 194). Başka bir ifadeyle müzik sanatı, görüngüler dünyasının değil, istencimizin, dolayısıyla da ideaların dünyasının bir ürünüdür. Schopenhauer'a göre "Müziğin etkisinin öteki sanatlardan daha güçlü olmasının, onun insanın içine işlemesinin nedeni budur. Çünkü onlar olsa olsa 
gölgeden söz eder, oysa müzik özü söyler” (Schopenhauer, 2009: 196-197). Schopenhauer, ideaları referans göstererek kullandığı isteme ve istenç kavramlarıyla, Platon'un sadık bir izleyicisi gibi bir izlenim bırakmaktadır. Schopenhauer'da müziğin özü söylemesi iddiası, ideaların özlerle olan ilişkisi göz önüne alındığında öncüllerini Platon'da bulmaktadır. Ancak Platon'un felsefesinde sanata verdiği yer idealar olmaktan çok uzaktır. Sanat, ideaların taklidi olan görüngülerin de taklididir. Platon'a göre idealar sadece özleri ifade etmektedir. Bununla birlikte Platon müziği bir sanat olarak görmesi yaşadığı dönem itibariyle imkansızdır. İdealar, en yüksek idea olan iyi ideasının şemsiyesi altında birleşerek etik bir alan oluşturur. Bu bağlamda Schopenhauer'un müziği idealarla temellendirmesi 19. yüzyılın ilk yarısında estetik ve müzik estetiği adına sanata bir varlık alanı açılmasıyla ilişkilendirilebilir. Dolayısıyla Schopenhauer'un müziğin idealara bağlama arzusu kendisinden önceki tartışmalar gibi etiğin değil, tamamiyla sanatsal bir hadisenin ifadesidir.

Schopenhauer'un müzik sanatıyla ilgili düşünceleri; müzikal ezgilerin amacının duyguların anlatımından başka bir şeyi ifade etmemesi, herhangi başka bir anlam yüklenmemesi ve doğası gereği çok düşünmeden duygulara özdeş olarak oluşturulması yönündedir. Bundan dolayı da müzik sanatı diğer bütün sanatların en üstündedir. Peter Kivy’e göre;

“Onun (Schopenhauer) düşüncesinde, güzel sanatların içinde en önde müzik (sanatı) gelir, çünkü müziğin yansittığl ve tasvir ettiği bu evrensel istenç, diğer sanatların yaptı̆̆ını daha doğrudan yapar. Schopenhauer müziği, istencin doğrudan kopyası olarak adlandırır. Bu müzik felsefesi için önemli bir vargıdır, 19. yüzyıl filozoflarının gözünde, müziğin biçimine diğer sanatların da üzerinde bir yer açarak onu hak ettiği seviyeye getirmiştir. (Kivy, 2010: 21).

Schopenhauer, her ne kadar müzik için sanatsal bir varlık alanı yapılandırma temayülünde olsa da, müziğin sadece sanat adına üretmek için, zorlama bir şatafatlılık içinde gösterilmesinin, sanatın ilkeleriyle pek uyuşmadığını kabul etmektedir. Bununla birlikte Schopenhauer'a göre, müziğin söze uyumlu olması için zorlama bir şekilde kiliselerde, operalarda kullanılması ve onu dansın, bandonun vb. bir şeyin müziği olarak belirli kalıpların içine sıkışıp kalması, sanatın doğasına uygun değildir (Schopenhauer, 2000: 430-431). Başka bir ifadeyle Schopenhauer müzik sanatını doğallık içinde ve yalın bir sanat olarak tahayyül etmektedir. Ezgilerin duygusal derinliği de bu yalınlıktan gelirken, çekicilik olarak kabul edilebilecek aşırı süslülük müzik sanatına zarar verebilir. Schopenhauer bu konu ile ilgili düşüncelerini aşağıdaki gibi örneklendirir.

"Müziğimizin tuttuğu yanlış yol ve başına gelmek üzere olan felaket son imparatorlar döneminde Roma mimarisinin tuttuğu yola ve başına gelen felaketlere benzemektedir. Bu dönemde mimari basit ve temel olanlarl klsmen gizleyen ve bir ölçüde tersine çeviren bezeme ve süslemelerle doldurulmuştu. Nitekim müziğimiz de bize bugün bir ylğın gürültü, çok sayıda enstrüman, fazlaca sanat, ama çok az açık, içe işleyici ve tesir edici tasavvur sunmaktadır" (Schopenhauer, 2013: 50).

Schopenhauer'a göre göre opera sanatında müziğii, tragedya, dans ve libretto (operaların yazılı metni) ile birleştirmek, abartılılık, haz düşkünlüğü ve gösterişlilikten başka bir şeyi ifade etmemektedir. Bir Schopenhauer hayranı olan Wagner' in övgü dolu yazdığı mektuba cevaben Schopenhauer'un İsviçreli gazeteci Arnold Wille'ye sarf ettiği sözleri Cartwright bize şöyle aktarmaktadır; "ona müzik yazmayı bırakmasını söyle. Bir şair olarak daha üstün kabiliyete sahip. Schopenhauer olarak ben, Rossini ve Mozart'a sağdığım” (Cartwright, 2014: 473). Schopenhauer'un bu ifadesinden de anlaşılacağı gibi sanat ve estetikle ilgili düşüncelerinde ortaya koyduğu eleştirilerden payını alan sanat dallarından birisi de opera sanatıdır. Wagner için sarf ettiği bu eleştiri tamamen onun gösterişli, uzun, abartı konularına ve zaman zaman 
müziğin önüne geçen ağır librettolarına yapıyor olmasından kaynaklanmaktadır. Schopenhauer'un abartılılık, haz düşkünlüğü ve gösterişle suçladığı opera sanatına ait düşüncelerinin kaynağı o dönemin (müzikte romantik dönem) sanat anlayışından kaynaklandığını da akıllara getirmektedir. Daha açık bir şekilde ifade edilmesi gerekirse, Schopenhauer'un eleştirileri opera sanatının bizzat kendisine olmamakla birlikte, bu sanatın Wagner'in yaptığı gibi, pek çok sanatları içinde barındırması özelliğinden dolayı zaman zaman abartılılığa kaçmasına yönelik olmasından kaynaklanmaktadır. Nitekim, Rossini'nin ve Mozart'in sade ve gösterişten uzak müziklerini eleştirmek şöyle dursun, Schopenhauer'un bu müzisyenlere karş1 gösterdiği sadakat, ideal bir sanat olarak operanın, müziğin önüne geçmesinden ziyade müziğin operayı temsil etmesinin olanakları olduğu sonucuna ulaşmaktadır. Schopenhauer opera sanatıyla ilgili düşüncelerini şu şekilde özetler "Mümkünse eğer operayı tek sahne ve bir saatle sınırlamak için yoğunlaştırıp kısaltmaya dönük teşebbüste bulunulmalıdır" (Schopenhauer, 2013: 56). 1851 yılının sonunda Wagner, döneminin piyano dâhisi olan Liszt ile genel olarak inanç konusunda girmiş oldukları tartışmanın neticesinde aralarının açılmasına istinaden savunma niteliğinde bir mektup yazar. Bu mektuptaki fikirlerini Schopenhauer'u referans göstererek yazması, oldukça ironik bir durum olarak algılanmaya müsaittir. Bu ironi; Wagner Liszt'e, hayranı olduğu bir filozof olan Schopenhauer'un felsefesini över ve ondan örnek verir (Merrick, 1987: 43). Schopenhauer'un sanat felsefesini yapılandırırken eleştirdiği, özellikle de şatafatlı, abartılı ve aşırı gösterişli sanat anlayışı eleştirisinin en büyük hedefi Wagner ve Liszt'dir. Aynı zamanda Schopenhauer'un sanat üzerine sarf ettiği düşüncelerin hiç birinden Liszt' in haberi dahi yoktur. Bu ironi, sanatı temsil edenlerin (Kant ve Schopenhauer onları dahi olarak adlandırmıştır) içinde yaşadığı dönemde mevcut olan sanat tartışmalarından ya habersiz, ya da üstüne alınmayan bir tavır içerisinde olduklarını göstermektedir. Başka bir ifadeyle Schopenhauer'un yaşadığı dönemde, sanatın felsefesi ile icrası, yani filozoflarla sanatçılar, birbirlerinden kopuk bir tablo içinde yer almaktadırlar. Schopenhauer'un tam olarak altını çizmek istediği konu kendini bu örneklerde hissettirmektedir. Şöyle ki, Schopenhauer sanatı, özellikle de müzik sanatının ifadesini ve verdiği duyguları kendisine problem edinmiş ve bu doğrultuda müzik sanatını idealara yakın görmüştür. Saf müzik (pure music) olarak ele aldığı örnekleri, sadece sanatı önemseyen Mozart gibi, Rossini gibi bestecileri referans göstererek oluşturmuştur. Bu bestecilerin sanatı saf olarak görmelerinin tek amacı, ilgi alanlarının saf bir şekilde sanatla dolu olması ve bunun dışında zorlama bir şekilde felsefi, politik ve kültürel bir ifade gereksinimleri duymamalarından kaynaklanmaktadır. Schopenhauer'un saf müzik düşüncesi etkisini günümüze kadar göstermektedir. Sanat felsefesi ve özellikle müzik felsefesi alanlarında çalışmalar yapan çağımızın en önemli filozoflarından Peter Kivy de müzik sanatını diğer sanatların ${ }^{4}$ bir karışımı veya birleşimi olarak düşünmemektedir. Kivy'e göre müzik diğer sanatlardan farklıdır, sadece müzik sanatı, sanatın diğer bütün öğelerinden (yazılı veya sözlü metin, görsel ifade vb.) bağımsız bir şekilde, saf müzik (pure music) olarak varlık gösterebilir (Kivy, 1993: 361). Kivy'nin bu düşüncesinin temelleri Schopenhauer'a dayanmaktadır. Schopenhauer'un müzik felsefesine yaptığı en önemli katkı müziğin saf bir halde, Platon'un şölen diyaloğunda güzel kavramından bahsettiği gibi kendinde, kendisinin nedeni olarak (kendinde müzik) ortaya koymasidir.

Schopenhauer'un Wagner'in sanatına olan tepkisi de saf sanat noktasında gelmektedir. Wagner'in sanatçı kişiliği; filozof, şair, besteci ve yazar olarak saf sanatın önüne geçmekte ve böylece Schopenhauer'a göre, müzik sanatı kendisini gerçekleştirememektedir. Schopenhauer' dan yaklaşık olarak bir asır sonra yaşamış olan ontolojik estetikçi Hartmann'ın, sanat üzerine yapılan tartışmalarda dile getirdiği, sanatın sanatçıya bırakılmayacak kadar değerli olduğu görüşü (Erenözlü, 2019: 104) öncüllerini Schopenhauer'da bulmaktadır. 
Schopenhauer'un müzik yaklaşımında, Antik Yunandan süregelen teori çalışmalarının izlerini de bulmak mümkündür. Bu çalışmalar, kendini en belirgin biçimde Sokrates öncesi filozoflardan Herakleitos' $\mathrm{da}^{5}$ ve Boethius'ta göstermektedir. Herakleitos'a göre, her şey zitlıktan doğar ve zitlıkların birleşmesi de uyumu (harmony) oluşturur (Herakleitos, 2016: 1718). Antik çağda bilim, sanat ve felsefe ayrı disiplinler olarak değil; matematik, geometri, astronomi ve müziği içine alan dörtlü sanatlar (quadrivium) ile mantık, retorik ve gramer konularından oluşan üçlü sanatların (trivium) birleşmesiyle meydana gelen, yedi özgür sanatın (septem artes liberales) kapsamında ele alınmaktaydı (Shiner, 2013: 57). Dolayısıyla Herakleitos'un çalışmalarında müzik felsefesinin izleri, ayrı bir disiplin olarak ele alınmamalı ve bu geleneğin Rönesans dönemine kadar devam ettiği göz önünde bulundurulmalıdır. $\mathrm{Bu}$ bağlamda Herakleitos'un harmoni olarak kullandığı terim, evrenin ve müziğin kendi içindeki uyumlarını ifade etmektedir (Tunal1, 2008: 56). Başka bir ifadeyle, Antikçağda uyum (harmony) ve oran (ratio) birbirini tamamlayan iki kavramı ifade etmektedir. Herakleitos ve Pythagoras müziğin kendi içindeki uyumların üzerine eğilirken, evrende de aynı uyumun mevcut olduğunu iddia etmektedirler. Antikçağdaki pek çok tartışmanın tekrar Ortaçağda alevlenmesi kendisini müzik araştırmalarında da göstermektedir. Boethius, Herakleitos ve Pythagoras'ın izinden giderek beş ciltten oluşan Müzik Araştırmaları (De instituione musica) adlı kitabında bu uyumu, kozmik müzik ${ }^{6}$ ayrımı ile ortaya koyar. Kozmik müziğin konusu, müziğin genel uyumunun oranları ile notalar arasındaki mesafelerin oranının, prensip olarak gezegenlerin aralarındaki uyum ve oranlarla aynı ilkelere sahip olduğu ile alakalıdır (Chadwick, 1998: 81). Schopenhauer'un müziğin felsefesini teori ve matematik (uyum) olarak ele alma şekli, Antikçağ ve Ortaçağın doğa ${ }^{7}$-müzik anlayışının bir devamı niteliğindedir. Müzikte en alt notalar olan bas (kalın) seslerle, onlara eşlik eden tiz (ince) sesler arasındaki uyum, organik doğa ile inorganik doğa arasındaki uyuma benzerdir. Schopenhauer, müzikte bas seslerin isteme (idealar) olarak inorganik dünyayı, tiz seslerin ise istemenin nesnelleşmesi olarak organik dünyayı temsil ettiğini iddia eder (Schopenhauer, 2009: 197). Bu bağlamda Schopenhauer, bas seslerle tiz seslerin birbirinden ayrılamayacağı ve bu ikisinin uyumunun müzik sanatını var edeceği düşüncesini, idealardan kaynaklı isteme ile maddede varlık gösteren dünyayı, müzikte kalın ve ince seslerin uyumu arasındaki analojiyle açıklamıştır.

Müziğin yapı taşlarından birisi olan dissonans (uyumsuz) seslerin, özellikle consonans (uyumlu) seslere çözülmeleriyle birlikte müzik sanatının armonik sistemi meydana gelir. Aksi takdirde müzikte kadans (bitiş) etkisinin yaratılması olanaklı gözükmemektedir. Başka bir ifadeyle diğer sanatların da vazgeçilmez ilkelerinden, belki de en önemli ilkelerinden birisi olan kontrast (zitlık) özelliğinin müzikte kendini göstermesi bu uyumsuz seslerin uyumlulara çözülmesidir. Müziğin araştırılmasında, zıtlıkların kendi içindeki uyumlarının ele alınış şekli, bir kez daha Antikçağın alakasındaki problemlerin, müzik düşüncesi üzerinde göstermiş olduğu etkiyi gözler önüne sermektedir. Schopenhauer'a göre "belirli aralıklar vermeyen, tınlamayan uyumsuz akorlar, iki farklı türden hayvanın birleşmesinden doğan piçlerle karşılaştırılabilirler" (Schopenhauer, 2009: 198). Schopenhauer'ın eski felsefe geleneğinden taşıdığı bu ilkesel uyumsuzluk, özellikle kendisinden sonra ortaya çıkan çağdaş müziğin de en önemli yap1 taşlarını meydana getirmektedir. Schopenhauer'un görüşünün tam tersinde yer alan çağdaş müzik, müziğin doğasında zitlıkların olması ve müziğin zitlıklardan oluşması olarak ortaya çıkmaktadır. 20. yüzyılın başlarında Webern, Schönberg'in yeni müzik (atonal music) adını vermeyi uygun bulduğu çalışmasıyla ilgili düşüncesini şu şekilde aktarır.

"Bildiğim kadarlyla ilk defa Schönberg dile getirmişti: bu nota komplekslerine consonanslar adını veriyor, ancak çok geçmeden dissonans denilen üst armonik ilişkilerinin birbirinden uzak oldukları ölçüde güzel duyulduğu anlaşıldı. Buna rağmen consonanslarla dissonanslar arasında temelde bir ayrım olmadiğını, bunlar arasında yalnızca bir derece farkı olduğunu anlamalıyı (...) Schönberg'in çok fazla dissonans 


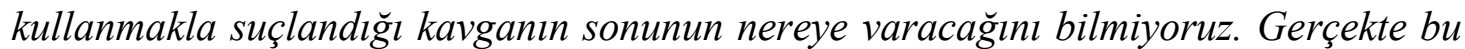
suçlama anlamsızdır; çünkü müzik bu kavgayı çok eski zamanlardan beri sürdürüyor"” (Webern, 1998: 24).

Webern'in dile getirdiği uyum (consonans) ve uyumsuzluk (dissonans) problemi müziğin temel problemi olarak antikiteden beri süregelen belirli bir felsefi birikimin yansımasıdır. Schopenhauer'un önemi ise bu tartışmaları kendisinden sonrakilere aktaracak bir köprü görevini yerine getirmiş olmasıdır.

\section{SONUÇ}

Müzik sanatının felsefeyle olan serüvenine kabaca bir göz atıldığında; Antikçağda Herakleitos (İ.Ö. 540-480) ve Pythagoras (İ.Ö. 580-500) matematiksel bir perspektiften bakarak müzik ile evren arasındaki orandan, Platon (İ.Ö. 428-348) ve Aristoteles (İ.Ö. 384-322) ise eğitim ve ahlak konularından ele almıştır. Ortaçağda aynı konulara olan ilginin devam etmesinden sonra Yeniçağda; Descartes (1596-1650), Leibniz (1646-1716) ve Rousseau (17121778) müziği matematiksel ve teknik olarak ele almıştır (Green, 1930: 199). Bütün bu yaklaşımlar felsefenin rehberliğinde müzik sanatın -neliğine veya ne hissettirdiğine ilişkin birtakım bilgiler içermemektedir. Kant'la başlayan Alman idealizminde, müzik felsefesine olan yaklaşımlar öznenin merkeze alınmasıyla farklı bir perspektif kazanmış olsa dahi, sanat felsefesi konusu olarak güzelin, yücenin ve dehanın araştırılmasından öteye gidilememiş, müziğin kendisinin felsefesi ilgisiz kalmıştır. Bu bağlamda Schopenhauer'un müzik felsefesiyle bu kadar yakından ilgileniyor olması, yaşadığı çağa hakim olan "müziğin üzerine fazla düşünmeme" geleneğinin de etkisinin kırılmasında önemli bir rolü olduğunun kabulünü gerektirir. Nitekim Schopenhauer'dan sonra, özellikle sanat ontolojisi kapsamında ele alınan müzik felsefesi problemleriyle beraber, felsefi yapıtlarda müzik sanatının üzerine daha fazla durulmuştur.

İsteme ve Tasarım Olarak Dünya adlı eserinin çok kapsamlılı̆̆1 içerisinde müzik felsefesine yönelik araştırmalar da yapmayı hedefleyen Schopenhauer, okuyucunun kendisini veya müzik felsefesini daha iyi anlaması için mutlak suretle müzik dinlemesi gerektiğini önemle belirtmektedir (Schopenhauer, 2009: 196). Bu bağlamda Schopenhauer, uygulama (pratik) ile tekniğin (teori) bir bütün içinde ele alınma zorunluluğunun, sağlıklı ve tutarlı bir müzik felsefesi çalışması adına en uygun yol olduğunu iddia etmektedir. Aksi taktirde müzisyenlerin uygulamaya dönük birikimleriyle, filozofların düşünce biçimleri birbirlerine yabancı olacak ve her iki gurup da birbirlerinin ne dediğini anlamayacak kadar kendi dizgesinin mahkumu olacaklardır. Ancak Schopenhauer'un felsefesi, bu iki alanın ayrı rolleri olduğunu ve saf sanat adına sanatçının sanat birikimi ile, filozofun felsefi birikiminin birbirine karıştırılmaması yönünde olduğunun da altını çizmektedir.

Schopenhauer'un müzik üzerine düşüncelerine eleştiri getirilebilecek en önemli nokta, müzik sanatını sanatların en üstünde görerek onu idealarla temellendirmesi üzerinedir. $\mathrm{Bu}$ eleştiri, Schopenhauer'un felsefesinin temel ilkesini oluşturan özne-nesne ilişkisiyle, başka bir deyişle isteme ve tasarım veya istemenin nesnelleşmesi yaklaşımlarıyla, ortaya koyduğu müzik felsefesi arasındaki çelişkidir. Bu çelişki, felsefesinin genel dizgesini oluşturduğu özne-nesne arasında kurduğu bağın, müzik felsefesinde yıkılması ile meydana gelmektedir. Dolayısıyla akıllara Schopenhauer'un müzik felsefesinde öznenin ve nesnenin (istemenin nesnelleşmesi) yerinin ne olduğu sorusu gelmekte ve müzik sanatının idealarda sıkışıp kaldığı gibi bir sonuca ulaşılmaktadır.

Sonuç olarak Schopenhauer'un müziğin felsefesini ele aldığı çalışmasında, müziğin duygusuna (emotion) olan yaklaşımlarının, belirli bir dizge içerisinde oluşturmaktan uzak olduğu kabul edilse bile, müzik felsefesi olarak müzik sanatını duygunun bir aktarımı ve ifadesi olarak en kapsamlı biçimde ele alan ilk filozof olduğu da kabul edilmelidir. Sanat üzerine olan 
çalışmaları başta Kant olmak üzere, Platon, Aristoteles ve ilk Yunanlıların çalışmalarının bir derlemesi olduğunun kabul edilmesi de olanaklı gözükmektedir. Kivy’nin Müzik Felsefesi adlı çalışmasında belirttiği gibi, Schopenhauer'un müzik üzerine olan düşüncelerinde birçok filozofun ve müzik teorisyeninin düşüncelerini yansıttığı görüşü (Kivy, 2010: 20), bu çalışmanın bulgularını desteklemektedir. Schopenhauer'un çalışmalarının bir müzik felsefesi olarak adlandırılması, ancak bu sanat dalının müziğe ait duyguların ifadesinin araştırılmasıyla sınırlıdır. Schopenhauer'un, müziği bu şekilde ele almış olması müzik felsefesi adına bir devrim niteliğindedir. Onun bu çalışması kendisinden sonra başta Eduard Hanslick'in On The Musically Beautiful (1854) olmak üzere müziğin duygularının araştırılması için uygun bir zemin hazırlamıştır. Bu bağlamda Schopenhauer'un müziğe yönelik çalışmaları sistemli bir müzik felsefesi teorisi olmak yerine, müziğe ait duyguların araştırılmasına yönelik bir çalışma olduğunun kabulü olanaklı gözükmektedir. 


\section{KAYNAKÇA}

CARTWRIGHT, D. E. (2014). Scopenhauer. (Çev. Erduman, S.) İstanbul: İşbankası.

CHADWICK, H. (1998). Boethius. The Consolations of Music, Logic, Theology, and Philosophy. Oxford Universty Press.

ERENÖZLÜ, S.S. (2019). Kant Estetiğinin Modern Düşüncede Eleştirisi, Doktora Tezi, Akdeniz Üniversitesi Sosyal Bilimler Enstitüsü.

GREEN, L. D. (1930). Schopenhauer and Music. Oxford Universty Press, The Musical Quarterly. Vol.16 No:2.

HEGEL, G.W.F. (2011). Tinin Görüngübilmi. (Çev. Yardımlı, A.) İstanbul: İdea Yayınevi.

HEGEL, G.W.F. (2004). Introductory Lectures on Aesthetics. (Trans. B. Bosanquet). London: Penguin Books.

HERAKLEITOS. (2016). Fragmanlar. (Çev. Akgün, A.) İstanbul: Kabalcı Yayınları.

IŞIM, M. A. (1976). Upanişadlar. İstanbul: Dergah Yayınları.

KANT, I. (1952). The Critique of Judgement. (Trans. J. C. Meredith). Oxford University Press.

KIVY, P. (1993). The Fine Art of Repetition. Cambridge University Press.

KIVY, P. (2010). Introduction to a Philosophy of Music. Oxford University Press.

LUKACS, G. (2001). Estetik. III.(Çev. Cemal, A.) Istanbul: Payel.

MERRICK, P. (1987). Revolution and Religion in the Music of Liszt. Cambridge University Press.

SAUNDERS, T.B. (2006). Schopenhauer. (Çev. Aydoğan, A.) İstanbul: Say.

SCHOPENHAUER, A. (2009). İsteme Ve Tasarım Olarak Dünya. (Çev. Özyaşar, L.) İstanbul: Biblos.

SCHOPENHAUER, A. (2000). Parerga and Paralipomena. (trans. Payne, E.F.J.). Oxford Universty Press.

SCHOPENHAUER. A. (2013). Güzelin Metafiziğii. (Çev. Aydoğan, A.) İstanbul: Say

SHINER, L. (2013). Sanatın İcadı Bir Kültür Tarihi. (Çev. Türkmen, İ.) İstanbul: Ayrıntı Yayınlar1.

SANS, E. (2006). Schopenhauer. (Çev. Ergüden, I.) Ankara: Dost.

TUNALI, İ. (2008). Grek Estetik’i. Ankara: Remzi Kitabevi.

WEBERN, A. (1998). Yeni Müziğe Doğru. (Çev. Bucak, A.) İstanbul: Pan Yayıncılık. 


\section{NOTLAR}

${ }^{1}$ Bir diğeri de Hanslick'in 1854 yılında yaptığı çalışma olan Müzikal Güzel Üzerine'dir.

${ }^{2}$ Upanişad adı verilen metinler, tarihin en eski düşüncelerinden birisi olan Hindistan kültürü ve bilgeliğine aittir. Günümüzden yaklaşık dört bin yıl öncesine ait olan Hindu kutsal metinleri en eski dini ve felsefi yazılı eserlerdir. Bkz. Derleyen: Mehmet Ali Işım, Upanişadlar “Tanrının Soluğu”, Dergah Yayınları, İstanbul, 1976, s.7-9.

${ }^{3}$ Mimesis, Platon'un felsefe sisteminde, sanat eserinin ideaların bir kopyası olduğu anlamına gelmektedir. Schopenhauer'da ideanın nesnelleşmiş hali sanat eseridir.

${ }^{4}$ Kivy'nin burada kullandığ1 "sanatlar" ifadesi, Kristeller'ın 1951'de yayımlanan Sanatların Modern Sistemi (The Modern System of the Arts) adlı makalesini referans göstermektedir. Kristeller'a göre bu beş büyük sanat; resim, heykel, mimarlık, müzik ve şiirdir. (Kivy, 1993: 360).

${ }^{5}$ Müziğin ve evrenin uyumundan ilk defa bahseden filozof Herakleitos olmuş olsa da, bu düşünceyi matematik ile ele alarak temellendirenler Pythagoras ve Pythagorasçılar olmuştur. Bkz. İsmail Tunalı, Grek Estetik'i, Remzi Kitapevi, Anlara 2008, s.57.

${ }^{6}$ Boethius Latince yazdığı Müzik Araştırmaları (De instituione musica) adlı kitabında, müziği üç kısma ayırır. Bunlardan ilki, kozmik müzik(Musica mundana), ikincisi insan müziği (Musica humana) ve üçüncü olarak Enstrüman müziğidir (Musica instrumentalis) (Chadwick, 1998: 81).

${ }^{7}$ Antik Yunan felsefesinde doğa anlayışı, bir arkhe arayışı olarak evrenin ontolojik araştırmasını içeren kozmoloji ve evrenin başlangıcı ile sonunu inceleyen kozmogoni konularını içine alan bir kümeyi kapsamaktadır. Dolayısıyla doğa, evreni temsil etmektedir. 